\title{
Geomorphological Instantaneous Unit Hydrograph (GIUH) for an Ungauged Watershed
}

\author{
B. N. Malleswara Rao \\ Professor, CVR College of Engineering/Civil Engineering Department, Hyderabad, India \\ Email: bnmrao@gmail.com
}

\begin{abstract}
In the present micro climate change conditions, there is a need for managing the available water resources and their optimum utilization for various purposes. This work aims at developing the Geomorphological Instantaneous Unit Hydrograph (GIUH) by using rainfall-runoff characteristics of an unguaged basin. The rainfall-runoff relationship can be developed using different empirical and conceptual methods. The empirical models are site specific. One has to develop separately for each basin. But earlier models were developed with few fixed parameters applicable to all the basins. A conceptual model developed by Rodriguez-Iturbe and Valdes relates the peak runoff and time to reach peak (unit hydrograph parameters) with the Geomorphological parameters of the basin. Remote sensing images and Survey of India toposheets are used to calculate these parameters in the present study. Basin parameters can be modified considering user needs with the help of GIS software. The study area chosen is the Khanapur watershed which is an unguaged lying in the mid Godavari basin. GIS database is developed using the basin parameters namely, drainage network map, slope map, land use / land cover map, and contour map in the analysis to find the Nash GIUH model parameters.
\end{abstract}

Index Terms: Unit hydrograph, unguaged, runoff, watershed, time of concentration, Geographic Information System, GIUH.

\section{INTRODUCTION}

I. Rodriguez-Iturbe and Valdes [9] introduced the concept of the Geomorphologic Instantaneous Unit Hydrograph (GIUH) to link the hydrologic characteristics of a basin with the geomorphologic parameters. The GIUH method can be used for unguaged basins, wherein rainfall data is available but runoff data is not available. Also GIUH having advantage to the other methods, as it does not require rainfall and meteorological data of other catchments in the region. Earlier works of A. N. Strahler [2], F. F. Snyder [8], R. E. Horton [16], A. B. Taylor and Schwartz [1] have provided an understanding of basin geomorphologyhydrology relationship through empirical relations. Further advancement was made by following researchers like C. O. Clark [6], J. E. Nash [11] and Koutsoyiannis and Xanthopoulos [14]. Literature study highlights the advantage of parametric approach for the derivation of unit hydrograph to establish a relationship between the Unit Hydrograph and basin characteristics.

A stream of a certain order with a linear response function was used in the derivation of the GIUH by following researchers like D. Ros [7], I. Rodriguez-Iturbe and Valdes [9], Kirshen and Bras [13], A. Rinaldo et al., [3], Jin [12], C. Fleurant et al., [5]. GIUH approach is applicable in situations where rainfall data is available but no runoff data is available. It is a more powerful technique for the estimation of peak run-off. The Nash-IUH model parameters and GIUH was linked by N. R. Bhaskar et al. [15]. GIUH technique is also useful in deriving the unit hydrograph (UH) using the geomorphologic characteristics (I. Rodriguez-Iturbe and Valdes [9], R. Rosso, [19], B. Sahoo et al., [4], R. Kumar et al., [17] and R. Kumar et. al. [18] studied the performance of Clark and Nash model by equating this model runoff peak to the peak runoff of GIUH model. This approach includes finding of Clark and Nash model parameters by assuming known peak runoff of GIUH model. In the present study, GIUH-based Nash model is used for the estimation of floods in unguaged watersheds with a reasonable degree of accuracy.

\section{STUDY AREA}

Khanapur watershed of Adilabad district which is the study area is a sub-basin of middle Godavari basin, lies in west of Adilabad in Telangana, comprising of five villages namely Khanapur, Dilawarpur, Tarlapadu, Gandhinagar and Maskapur. Fig. 1 shows the study area. The total area of the basin is $55.753 \mathrm{~km}^{2}$. Geographically it lies between the Longitudes of 78.34'33" $\mathrm{E}$ to $78^{\circ} 40^{\prime} 37^{\prime \prime} \mathrm{E}$ and Latitudes of $19^{\circ} 2^{\prime} 24^{\prime \prime} \mathrm{N}$ to $19^{\circ} 6^{\prime} 37^{\prime \prime} \mathrm{N}$. 


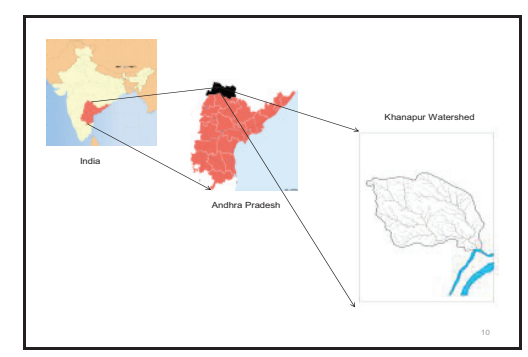

Figure 1. Location map for Khanapur watershed

\section{GIS DATABASE GENERATION}

Drainage map: Fig. 2 shows the drainage map. The study area drainage map consists of stream network and water bodies.

Soil map: Fig. 3 shows the soil map. It gives the information regarding different types of soils in the watershed. This data is useful in prediction of the runoff capability of different soils.

Contour map: Fig. 4 shows contour map. contour is an imaginary line joining the points of equal elevation, the highest elevation being +400 M.S.L.

All the above GIS maps will form the geographical data base of the watershed.

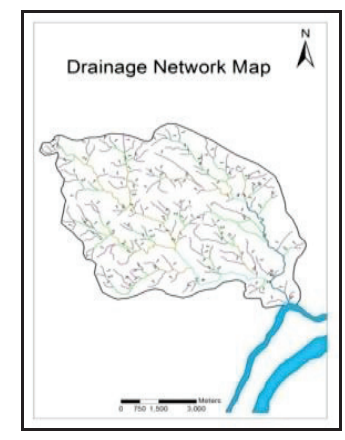

Figure 2. Drainage map

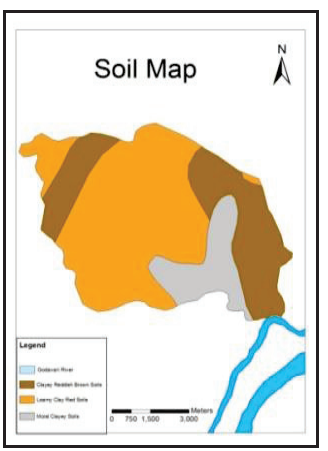

Figure 3. Soil Map

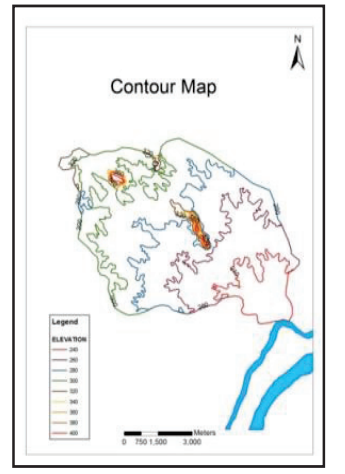

Figure 4. Contour Map

\section{DERIVATION OF NASH MOdel PARAMETERS From q AND $t_{P}$ OF GIUH}

Total Number of streams of different orders $\quad(N)=209$

Total area of the drainage basin $(\mathrm{A})=55.75 \mathrm{~km}^{2}$

Total length of the all streams $(\mathrm{L})=152.75 \mathrm{~km}$

Drainage density $(\mathrm{D})=\mathrm{A} / \mathrm{L}=0.365 \mathrm{~km}^{2} / \mathrm{km}$

Horton's stream-bifurcation ratio $\left(\mathrm{R}_{\mathrm{B}}\right)=2.98$

Horton's stream-length ratio $\left(\mathrm{R}_{\mathrm{L}}\right)=1.58$

Horton's stream-area ratio $\left(\mathrm{R}_{\mathrm{A}}\right)=2.60$

Mean stream length of highest order $\left(\mathrm{L}_{\mathrm{W}}\right)=2.98 \mathrm{~km}$

Time of concentration of a basin is estimated using geomorphologic data by applying the equations (1) and (2). Velocity relationship given by equation (8) is useful in estimating time of concentration for a watershed by using mean slope and land cover characteristics. Equations (7) and (8) are used in arriving a relationship between velocity, flow length and mean slope characteristics of a watershed which is presented by equation (9).

$t_{c}=0.01947 \cdot L^{0.77} \cdot S^{-0.385}$

$t_{c}=\frac{1}{60}\left(\frac{l}{V}\right)$

$V=0.8562 \cdot L^{0.23} \cdot S^{0.385}$

TABLE I.

MEASURED GEOMORPHOLOGICAL DATA

\begin{tabular}{|c|c|c|c|}
\hline 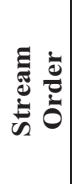 & 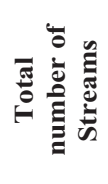 & 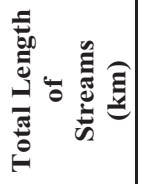 & 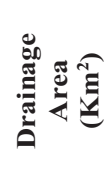 \\
\hline 1 & 144 & 88.1039 & 19.9757 \\
\hline 2 & 40 & 30.6626 & 14.7512 \\
\hline 3 & 18 & 22.1177 & 7.2726 \\
\hline 4 & 5 & 5.9093 & 4.3154 \\
\hline 5 & 2 & 5.9601 & 7.7953 \\
\hline
\end{tabular}


TABLE II.

DERIVED GEOMORPHOLOGICAL DATA

\begin{tabular}{|c|c|c|c|c|c|}
\hline 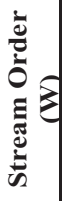 & 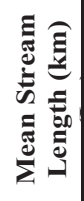 & 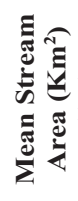 & 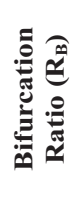 & 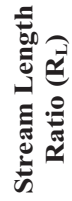 & 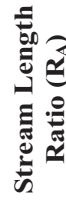 \\
\hline 1 & 0.61 & 0.14 & 3.60 & -- & -- \\
\hline 2 & 0.77 & 0.37 & 2.22 & 1.25 & 2.65 \\
\hline 3 & 1.23 & 0.40 & 3.6 & 1.60 & 1.09 \\
\hline 4 & 1.19 & 0.9 & 2.5 & 0.96 & 2.14 \\
\hline 5 & 2.98 & 3.9 & -- & 2.52 & 4.52 \\
\hline
\end{tabular}

Here $t_{c}=$ time of concentration in min.; $L=$ length of the main stream length in meter and $\mathrm{S}=$ mean watershed slope $(\mathrm{m} / \mathrm{m})$ and $\mathrm{V}=$ velocity in $\mathrm{m} / \mathrm{s}$.

J. E. Nash [10] suggested a conceptual model in which basin impulse response can be represented as the outflow obtained from routing the unit volume of the instantaneous excess rainfall input through a series of ' $n$ ' successive linear reservoirs having equal delay time. The following equation are given by Nash IUH model :

$$
U(0, t)=\frac{1}{k} \times \frac{1}{\Gamma(n)} \times e^{\left(\frac{-t}{k}\right)} \times\left(\frac{t}{k}\right)^{n-1}
$$

Where $\mathrm{U}(0, \mathrm{t})=\quad$ ordinate of the IUH

$$
\begin{array}{lll}
\Gamma & = & \text { gamma function } \\
\mathrm{K} & = & \begin{array}{l}
\text { catchment storage coefficient } \\
\text { (scale function) }
\end{array}
\end{array}
$$

and $\mathrm{n} \quad=\quad$ the number of linear reservoirs (shape parameter).

$q_{p} \times t_{p}=\frac{(n-1)}{\Gamma(n)} \times e^{-(n-1)} \times(n-1)^{(n-1)}$

Eq. (5) is a function of Nash IUH model parameters $n$ only.

The most important characteristic of an IUH are the peak $\mathrm{q}_{\mathrm{p}}$ and the time to peak $\mathrm{t}_{\mathrm{p}}$. I. Rodriguez-Iturbe and Valdes [9] noticed that $\mathrm{q}_{\mathrm{p}}$ and $\mathrm{t}_{\mathrm{p}}$ are simple related to the velocity $\mathrm{v}$. This when simplified the following equations (6) and (7) were obtained.

$\mathrm{q}_{\mathrm{p}}=\left(\frac{1.31}{L_{W}}\right) \times R_{L}^{0.43} \times v$ $\mathrm{t}_{\mathrm{p}}=\left(\frac{0.44}{v}\right) \times L_{W} \times R_{B}^{0.55} \times R_{A}^{-0.55} R_{L}^{-0.38}$

By multiplying (6) and (7), we will get $q_{p} \times t_{p}$ in terms of geomorphological characteristics.

$q_{p} \times t_{p}=0.5764 R_{B}^{0.55} \times R_{A}^{-0.55} \times R_{L}^{0.05}$

Equating (5) and (8), we have

$\frac{(n-1)}{\Gamma(n)} \times e^{-(n-1)} \times(n-1)^{(n-1)} 0.5764 R_{B}^{0.55} \times$

$R_{A}^{-0.55} \times R_{L}^{0.05}$

The $\mathrm{n}$ value which obtained from above equation may be substituted in the following equation which is derived from by combining (6) and (2) to get Nash model parameters $\mathrm{K}$ for a given velocity $\mathrm{V}$

$K=\frac{t_{p}}{n-1}=\frac{0.44}{v} \times L_{w} \times R_{B}^{0.55} \times R_{A}^{-0.55} \times$
$R_{L}^{-0.38} \times \frac{1}{n-1}$

\begin{tabular}{|c|c|c|c|c|c|}
\hline : & $\stackrel{2}{2}$ & 旁 & 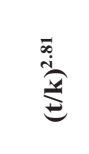 & $\widehat{હ}$ & 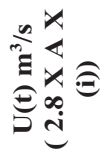 \\
\hline 0 & 0 & 1 & 0 & 0 & 0 \\
\hline 0.2 & 0.9 & 0.394 & 0.82 & 0.32 & 49.29 \\
\hline 0.4 & 1.9 & 0.156 & 5.73 & 0.87 & 136.3 \\
\hline 0.6 & 2.8 & 0.06 & 17.91 & 1.07 & 167.93 \\
\hline 0.8 & 3.7 & 0.024 & 40.19 & 0.95 & 148.6 \\
\hline 1.0 & 4.7 & 0.01 & 75.23 & 0.70 & 109.69 \\
\hline 1.2 & 5.6 & 0.004 & 125.6 & 0.46 & 72.2 \\
\hline 1.4 & 6.5 & 0.002 & 193.7 & 0.28 & 43.89 \\
\hline 1.6 & 7.5 & 0.001 & 281.8 & 0.16 & 25.19 \\
\hline 1.8 & 8.4 & 0.0002 & 392.4 & 0.09 & 13.83 \\
\hline 2.0 & 9.3 & $1 \times 10^{-4}$ & 527.6 & 0.05 & 7.33 \\
\hline 2.2 & 10.2 & $3 \times 10^{-4}$ & 689.6 & 0.02 & 3.78 \\
\hline 2.4 & 11.2 & $1 \times 10^{-5}$ & 880.7 & 0.01 & 1.90 \\
\hline 2.6 & 12.1 & $5 \times 10^{-6}$ & 1102.8 & 0.01 & 0.94 \\
\hline
\end{tabular}

TABLE III.

ORdinAtes of GiUH DeRIVED From NASH Model PaRAMETERS

\section{RESUlTS OF GIUH}

Equilibrium velocity

$V=0.8562 \cdot(14621.91)^{0.23} \cdot 0.02^{0.385}$

$V=1.723 \mathrm{~m} / \mathrm{sec}$ 
Area of the watershed $\quad A=55.753 \mathrm{~km}^{2}$

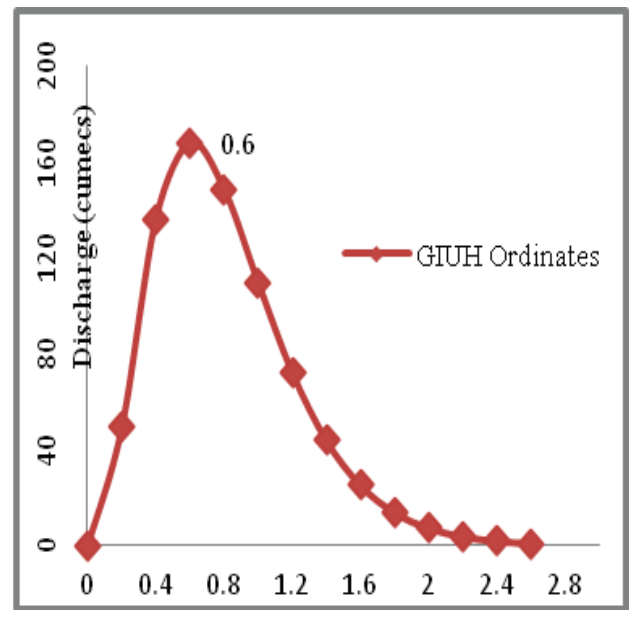

Time (hours)

Figure 5. Nash model IUH for Khanapur watershed

On solving equation (7) and (8)

The Nash Parameters $\mathrm{n}=3.81$

$$
\mathrm{K}=0.24
$$

The values can be utilized to derive the complete shape of GIUH using equation (4).

$U(0, t)=\frac{1}{k} \times \frac{1}{T(n)} \times e^{\left(\frac{-t}{k}\right)} \times\left(\frac{t}{k}\right)^{n-1}$

$U(0, t)=0.98 \times e^{\left(\frac{-t}{0.24}\right)} \times\left(\frac{t}{0.24}\right)^{2.81}$

\section{Derived Values of GIUH:}

From the figure 5, we can derive that

Time to peak, $\mathrm{t}_{\mathrm{p}}=0.6 \mathrm{hr}$

Base time, $\mathrm{t}_{\mathrm{b}}=2.6 \mathrm{hrs}$

\section{Theoretical Values of GIUH:}

$$
\begin{aligned}
& \text { Main Stream Length }(\mathrm{m}) \mathrm{L} \quad=14621.91 \\
& \text { Mean Slope of Watershed, } \mathrm{S}=2 \% \\
& \operatorname{Velocity}(\mathrm{m} / \mathrm{s}) \quad=0.8562 \times \mathrm{L}^{0.23} \times \mathrm{S}^{0.385} \\
& =1.723 \mathrm{~m} / \mathrm{s}
\end{aligned}
$$

Peak discharge, $\mathrm{q}_{\mathrm{p}}=1.31 \times \mathrm{R}_{\mathrm{L}}^{0.43} \times\left(\frac{V}{L \Omega}\right)$

$$
\begin{aligned}
&=1.31 \times(1.585)^{0.43} \times\left(\frac{1.723}{2.98}\right) \\
&=0.923 \mathrm{~h}^{-1} \\
& \text { Time to peak, } \mathrm{t}_{\mathrm{p}}=\left(\frac{0.44}{\mathrm{~V}}\right) \times \mathrm{L}_{\Omega} \times\left(\mathrm{R}_{\mathrm{B}} / \mathrm{R}_{\mathrm{A}}\right)^{0.22} \times\left(\mathrm{R}_{\mathrm{L}}\right)^{-0.38} \\
&=\left(\frac{0.44}{1.723}\right) \times 2.98 \times(2.981 / 2.601)^{0.23} \times(1.585)^{-0.38} \\
&= 0.7 \mathrm{hr} \\
& \text { Base time, } \mathrm{t}_{\mathrm{b}}=\frac{2}{\mathrm{q}_{\mathrm{g}}} \\
&=\frac{2}{0.923}=2.2 \mathrm{hr}
\end{aligned}
$$

\section{RESULTS AND CONCLUSIONS}

1.The soil map prepared can be used in the generation of the land capability map. The land capability map thus prepared is used for preparing land adjustment map which gives the information on cropping pattern adjustment needed for better agricultural production.

2. The drainage map shows the drainage pattern of the area, stream density and existing tank details. It also gives the information on tank condition i.e., details like water spread area, silted portion etc. This information is helpful to prepare plans for restoration of these deteriorated tanks.

3.The hydrogeomorphological data base shows the different geological formations, lineaments, geological faults etc. This information is helpful in finding water potential zones which in turn is useful in preparation of land capability map.

4.The hydrogeomorphological data is used in geomorphological analyses of the study area. The different geomorphological parameters obtained from the present study are as follows:

Total number of streams of different orders, $\mathrm{N}=209$

Total area of the drainage basin, $A=55.75 \mathrm{~km}^{2}$

Total length of all streams, $\mathrm{L} \quad=152.75 \mathrm{~km}$

Drainage density, $\mathrm{A} / \mathrm{L} \quad=0.365$

Horton's stream-bifurcation ratio, $\mathrm{R}_{\mathrm{B}} \quad=2.98$

Horton's stream-length ratio, $\mathrm{R}_{\mathrm{L}} \quad=1.58$

Horton's stream-area ratio, $\mathrm{R}_{\mathrm{A}} \quad=2.60$

Mean stream length of highest order, $L_{w}=2.98 \mathrm{~km}$

5.By using the geomorphological parameters, a Geomorphological Instantaneous Unit Hydrograph (GIUH) using Nash model parameters $n$ and $K$ values is developed. 
6.This GIUH model is useful in development of runoff in an event where the rainfall data is known.

7.The GIS database can also be used by officials to understand the activities in the watershed and analyze the temporal variations in this area.

\section{REFERENCES}

[1] A.B.Taylor and H. E. Schwartz,"Unit-hydrograph lag and peak flow related to basin characteristics", Trans. Amer. Geophys. Uni., vol. 33, pp. 235-246, 1952.

[2] A.N. Strahler "Quantitative analysis of watershed geomorphology",Trans. Amer. Geophys. Uni.,vol.38,pp. 913-920, 1957.

[3] A. Rinaldo, A. Marani and R. Rigon,"Geomorphological dispersion”, J. Water Resour. Res., vol. 27, pp. 513-525, 1991.

[4] B. Sahoo, C. Chatterjee, N. S. Raghuwanshi, R. Singh and R. Kumar, "Flood estimation by GIUH based Clark and Nash models", J. Hydrologic Engg., vol.11, pp. 515-525,

[5] C. Fleurant,B. Kartiwa, B. Roland, "Analytical model for 2006. ageomorphological instantaneous unit hydrograph", J. Hydrol. Process. vol. 20, pp. 3879-3895, 2006.

[6] C. O. Clark, "Storage and the unit hydrograph", Trans. Am. Soc. Civ. Engr., pg. 110, 1945.

[7] D. Ros, and M. Borga, "Use of digital elevation model data for the derivation of the geomorphological instantaneous unit hydrograph", J. Hydrol. Process., vol. 11, pp. 13-33, 1997.

[8] F. F. Snyder, "Synthetic unit graphs", Trans. Amer. Geophys. Uni., vol.2, pg. 447, 1938.

[9] I. Rodriguez -Iturbe and J. B. Valdes, "The geomorphologic structure of hydrologic response", J. Water Resour. Res., vol. 15, pp. 1409-1420, 1979.

[10] J.E. Nash,"The form of the instantaneous unithydrograph." Intern .Assoc.of Sci e.and Hydr.,Pub.45,vol.3, pp.114-121, 1957

[11] J. E. Nash, "A unit hydrograph study, with particular reference to British catchments", Proc. Inst. Civil Engg., vol. 17, pp. 249-282, 1960.

[12] Jin,"A determinitic gamma-type geomorphologic instantaneous unit hydrograph based on path types", J.Water Resour. Res., vol. 28, pp. 479-486, 1992.

[13] Kirshen, and Bras,"The linear channel and its effect on the geomorphologic IUH",J.Hydrol.vol.65, pp.175-208, 1983.

[14] Koutsoyiannis and Xanthopoulos, "On the parametric approach tunit hydrograph identification",J. Water Res. Manage., vol. 3, pp. 107-128, 1989.

[15] N. R. Bhaskar, B.P. Parida, and A.K. Nayak, "Flood estimation for ungauged catchments using the GIUH", J.WaterResour. Plann. and Manage. vol. 123, ASCE, 1997.
[16] R.E. Horton, "Erosional development of streams and their drainage basins: Hydro physical approach to quantitative morphology", Bull. Geol. Soc. Amer., vol. 56, pp.275-370,1945.

[17] R. Kumar, C. Chatterjee, A. K. Lohani, S. Kumar, R. D. Singh "Sensitivity analysis of the GIUH based Clark modelfor a catchment", J. Water Res. Manage., vol. 16, pp.263-278, 2002.

[18] R. Kumar, C. Chatterjee, R. D. Singh, A. K. Lohani and S.Kumar, "Runoff estimation for an ungauged catchment using geomorphological instantaneous unit hydrograph (GIUH) model", J. Hydrol. Process., vol. 21, pp. 1829-1840, 2007.

[19] R. Rosso, "Nash model relation to Horton order ratios",J. Water Resour., vol. 20, pp. 914-920, 1984. 